\title{
WSPÓŁCZESNE PROBLEMY I WYZWANIA ZARZĄDZANIA ZASOBAMI LUDZKIMI W ORGANIZACJACH MIĘDZYNARODOWYCH
}

\author{
Agnieszka Raczek \\ Politechnika Częstochowska \\ Wydział Zarządzania
}

\begin{abstract}
Streszczenie: Niniejszy artykuł podejmuje tematykę związaną z zarządzaniem zasobami ludzkimi w przedsiębiorstwach międzynarodowych. Usiłuje wskazać rolę działów zasobów ludzkich w obecnych czasach, które muszą niejednokrotnie wykazać się zarówno ogromną inicjatywą, jak i elastycznością w swoich codziennych aktywnościach, aby pełnić rolę nie tylko administratora danych personalno-płacowych, lecz znaczącą rolę strategicznego partnera biznesowego. Rozważania teoretyczne uzupełniono o studium przypadku prezentujące główne problemy w dziale HR w międzynarodowym przedsiębiorstwie.
\end{abstract}

Słowa kluczowe: zasoby ludzkie, zarządzanie personelem, przedsiębiorstwa międzynarodowe

DOI: 10.17512/znpcz.2016.2.15

\section{Wprowadzenie}

Współcześnie skuteczne zarządzanie zasobami ludzkimi wymaga rozumienia całości zagadnień związanych z funkcjonowaniem przedsiębiorstwa, dostosowaniem strategii i polityki personalnej do potrzeb strategii organizacji. Celem niniejszego artykułu jest teoretyczne przybliżenie problematyki zarządzania zasobami ludzkimi w przedsiębiorstwach międzynarodowych oraz wskazanie na problemy, $\mathrm{z}$ jakimi mają do czynienia $\mathrm{w}$ codziennej pracy osoby zatrudnione $\mathrm{w}$ działach $\mathrm{HR}$. Warto zauważyć, iż na przestrzeni kilkudziesięciu lat zmieniło się postrzeganie zasobów ludzkich oraz osób pracujących w działach HR (z ang. human resources). Nie wystarczy być już tylko kadrowym, zajmującym się wyłącznie administrowaniem danych personalnych, zakładaniem i prowadzeniem akt pracowników, lecz konieczne jest posiadanie świadomości i nastawienia biznesowego, rozumienie mechanizmów rządzących efektywnością firmy, posiadanie wiedzy z zakresu kompleksowego zarządzania przedsiębiorstwem. Duże znaczenie przypisuje się controllingowi personalnemu, dzięki któremu możliwe jest planowanie kosztów, a także analiza konkretnych danych liczbowych, jak na przykład koszty wynagrodzeń. Controlling personalny służy racjonalizacji zatrudnienia i ograniczaniu przypadkowości poprzez koordynację planowania, kontrolę i sprawne zasilanie informacyjne (Sajkiewicz 2004, s. 33). Współczesny pracownik działu HR powinien posiadać zatem rozległą wiedzę i kompetencje, umożliwiające pełnienie roli dorad- 
czo-wspierającej dla zarządów przy podejmowaniu strategicznych decyzji mających wpływ na globalne funkcjonowanie firmy. Rola ta jest $\mathrm{z}$ całą pewnością trudniejsza $\mathrm{w}$ przypadku przedsiębiorstw międzynarodowych, w których oprócz znajomości rozmaitych narzędzi i procesów HR należy wykazać się znajomością także kultury danego kraju, otoczenia rynkowego oraz mentalności pracowników.

\section{Miejsce i rola funkcji zarządzania zasobami ludzkimi w przedsiębiorstwach międzynarodowych}

Należy podkreślić, iż w obecnych czasach zasoby ludzkie mają ogromne znaczenie dla skutecznego, przynoszącego wymierne efekty funkcjonowania każdej organizacji. Jak zauważa R.W. Griffin: „Zarządzanie zasobami ludzkimi (albo - jak się je niekiedy nazywa - zarządzanie personelem) w wielu organizacjach zaliczano kiedyś do zadań drugorzędnych, ale w ciągu ostatnich dwóch dziesięcioleci jego znaczenie ogromnie wzrosło. Wynika to z rosnącej złożoności materii prawnej, z uznania, że zasoby ludzkie są cennym środkiem poprawy wydajności, i z uświadomienia sobie kosztów związanych z niewłaściwym zarządzaniem nimi”" (Griffin 2013, s. 441). Można zatem przyjąć, iż współczesne zarządzanie zasobami ludzkimi odgrywa rolę strategiczną. Zdaniem A. Pocztowskiego strategiczne zarządzanie zasobami ludzkimi ma swoje źródła w założeniach koncepcji zarządzania zasobami ludzkimi powstałej w Stanach Zjednoczonych w latach osiemdziesiątych XX wieku. Podejście to zakładało wówczas zupełnie odmienny jak na tamte czasy sposób postrzegania pracowników, mianowicie nie tylko w kategorii źródła kosztów, lecz także jako zasobu wiedzy, umiejętności oraz zdolności, pozwalających na uzyskanie przewagi konkurencyjnej (Pocztowski 2002, s. 37). A. Pocztowski wskazuje ponadto, że w dzisiejszych czasach takie podejście jest czymś oczywistym $\mathrm{w}$ definiowaniu ról pełnionych $\mathrm{w}$ ramach nowocześnie sprawowanej funkcji personalnej. Wśród nich należy wymienić rolę partnera strategicznego, rolę wewnętrznego dostawcy usług dla szeroko rozumianych klientów oraz rolę wewnętrznego konsultanta (Pocztowski 2002, s. 37). W kwestii pełnienia roli partnera strategicznego należy podkreślić fakt, iż często w zarządach firm międzynarodowych zasiada osoba HR menedżerów / dyrektora personalnego1, a jeśli taka sytuacja nie ma miejsca, to i tak pozycja w strukturach organizacyjnych tychże stanowisk jest bardzo wysoka, tzn. osoby te raportują zwykle bezpośrednio do prezesów zarządu. Biorą udział w spotkaniach kadry kierowniczej wyższego szczebla (w skład której również wchodzą), podejmując decyzje w tak ważnych sprawach jak wielkość i struktura zatrudnienia danej firmy, czy też poziom wynagrodzenia na poszczególnych stanowiskach. To od nich w dużej mierze zależą istniejące w firmie, bądź nie, systemy motywacyjne, czy też jakość i stopień realizacji polityki personalnej w firmach. Należy jednak pamiętać, że oprócz HR menedżerów / dyrektorów personalnych na jakość podejmowanych działań i sposób postrzegania firmy w kontekście mniej lub bardziej atrakcyjnego pracodawcy mają wpływ wszyscy pracownicy działów zasobów ludz-

\footnotetext{
${ }^{1}$ HR menedżer / dyrektor personalny - to najczęściej występujące w firmach (zwłaszcza z kapitałem zagranicznym) nazwy stanowisk osób odpowiedzialnych za zarządzanie zasobami ludzkimi. Warto jednakże brać pod uwagę zakres zadań przypisany do stanowiska, jak i poziom uprawnień i decyzyjności, a nie sugerować się wyłącznie samym nazewnictwem stanowiska.
} 
$\mathrm{kich}^{2}$. To ich podejście oraz poziom kompetencji, wiedzy i zaangażowania bezpośrednio wpływają na pozostałych pracowników danej organizacji. To dzięki nim w dużej mierze realizowana jest rola wewnętrznego dostawcy usług, rozumianego jako dostawca interesujących dla pracowników programów szkoleniowo-rozwojowych, systemowych rozwiązań motywacyjnych, atrakcyjnych pakietów socjalnych, przejrzystych i funkcjonalnych procedur etc. Pracownicy działów zasobów ludzkich pełnią ponadto niezwykle istotną rolę wewnętrznego konsultanta, aczkolwiek należy podkreślić, iż ażeby ta rola mogła być realizowana efektywnie, pracownicy tychże działów muszą posiadać oczywiście odpowiedni poziom wykształcenia, wiedzy, kompetencji, doświadczenia. Jak wskazują D. Ulrich i W. Brockbank, najlepszy dział zasobów ludzkich to dział, który stara się dostosować pracę do potrzeb klientów oraz dba o ich pozytywne wrażenia. Dział ten powinien ponadto czuwać, aby dobór pracowników, ich rozwój, system nagradzania i komunikacji w firmie kształtowały umiejętności niezbędne do zapewnienia satysfakcji klientów, a to z kolei pozwoli zdobyć ich lojalność (Ulrich, Brockbank 2013, s. 74). Swoista opieka nad personelem przynosi wiele osobistej satysfakcji pracownikom HR, aczkolwiek zdaniem wyżej wspomnianych autorów największe znaczenie $\mathrm{w}$ ich pracy mają funkcje rzecznika pracowników i dewelopera kapitału ludzkiego, gdyż pomagają one uchwycić zależności między zachowaniami pracowników a działaniem inwestorów, klientów i menedżerów liniowych. Specjaliści HR tworzą wartość dla personelu i stanowią duszę przedsiębiorstwa, kiedy realizują następujące zadania:

- Określają model wartości dla pracowników, dzięki czemu wiedzą, że są ważni dla firmy, a ich praca wnosi wartość.

- Reprezentują interesy pracowników w kontaktach z menedżerami liniowymi.

- Zapewniają wsparcie administracyjne pracownikom.

- Dbają, aby pracownicy zdobyli umiejętności pozwalające rozwijać potencjał firmy (Ulrich, Brockbank 2013, s. 74).

Specjaliści HR powinni dbać również o swój regularny rozwój poprzez uczestnictwo w szkoleniach, konferencjach branżowych, mieć dostęp do profesjonalnej literatury i z niej korzystać, monitorować rynek usług HR i aktualnie rekrutujących pracowników pracodawców. Jest to konieczne, aby posiadać bieżącą wiedzę na temat panujących trendów i ewentualnych zagrożeń, chociażby w postaci zbyt wysokiego poziomu rotacji. $\mathrm{W}$ przeciwnym razie specjaliści nie będą $\mathrm{w}$ stanie pełnić powyższych zadań, a brak należytej wiedzy stanowił będzie poważną przeszkodę w budowaniu wizerunku specjalisty w dziedzinie zarządzania zasobami ludzkimi.

Według M. Armstronga zarządzanie zasobami ludzkimi to strategiczne, spójne podejście do zarządzania najcenniejszym zasobem każdej organizacji - ludźmi, którzy w niej pracują i którzy indywidualnie oraz zbiorowo przyczyniają się do osiągania jej celów (Armstrong 2010, s. 13).

${ }^{2} \mathrm{~W}$ zależności od organizacji działy zasobów ludzkich mogą przybierać różne nazwy. Najczęściej spotykane to działy personalne, działy kadr, departamenty personalne, działy zasobów ludzkich. 
K. Gadomska-Lila przypomina, że zarządzanie zasobami ludzkimi osadzone jest $\mathrm{w}$ teorii zasobowej, której wybitnymi przedstawicielami są E.T. Penrose i B. Wernerfelt. Ludzie mogą stanowić ten szczególny zasób, który nadaje organizacji unikatowy charakter i szczególnie ją wyróżnia. W tym celu konieczne jest właściwe wykorzystanie potencjału pracowników: wiedzy, umiejętności, łącznie z potencjałem emocjonalnym, a to z kolei wymaga opracowania sprawnego systemu zarządzania (Gadomska-Lila 2013, s. 71).

T. Listwan podkreśla, iż obecnie ludzie w organizacji postrzegani są jako zasoby strategiczne, stwarzające możliwość uzyskania i utrzymania przewagi konkurencyjnej. Jest to możliwe przede wszystkim dzięki zdolnościom, kwalifikacjom oraz ich kreatywności i elastyczności w działaniu. To ludzie tworzą wartość dodaną, natomiast inne zasoby stanowią tylko przesłanki do jej wytworzenia. Ludzie są podstawowym komponentem firmy, również w sensie ich zawodności, wskutek czego stają się elementem krytycznym w funkcjonowaniu organizacji (Listwan 2010, s. 60). Traktowanie ludzi, ich cech i przymiotów jako kapitału pomaga w kształtowaniu kariery i rozwijaniu kwalifikacji pracowników w sposób zgodny z potrzebami i celami przedsiębiorstwa (Bylok, Słocińska 2011, s. 6). Powyższe definicje i stwierdzenia wyraźnie wskazują, jak ważne jest, aby osoby zajmujące się zarządzaniem zasobami ludzkimi były kompetentne i świadome spoczywającej na nich odpowiedzialności.

\section{Cechy funkcji zarządzania zasobami ludzkimi w przedsiębiorstwach międzynarodowych}

Aktualnie coraz więcej firm, niezależnie od wielkości, decyduje się na wyjście poza granice własnego kraju. Powodem tego może być poszukiwanie nowych klientów, dostawców, kontrahentów, bądź też sytuacja taka ma miejsce, gdy dochodzi do fuzji lub przejęć przez inne firmy (Stor 2010, s. 407-409). Pojawia się wówczas pojęcie międzynarodowego zarządzania kadrami (MZK), które według definicji T. Listwana „obejmuje zbiór decyzji i działań związanych z ludźmi, ukierunkowanych na osiąganie celów organizacji międzynarodowej i zaspokajanie potrzeb jej pracowników (Stor 2010, s. 407-409). Do zasadniczych filarów MZK należą komunikacja międzynarodowa i międzykulturowa. M. Stor wskazuje, iż zarządzanie kadrami w przedsiębiorstwach międzynarodowych staje się jednym z największych wyzwań, przed jakimi stają praktycy i teoretycy zarządzania w XXI wieku. Powodem tego jest fakt, iż decyzje i działania mają charakter znacznie bardziej skomplikowany aniżeli w przedsiębiorstwie krajowym, działającym na jednym rynku lokalnym, z którego firma się wywodzi. W przypadku firm międzynarodowych konieczne jest uwzględnianie wielu różnic w otoczeniu, zarówno na poziomie poszczególnych jednostek lokalnych, umiejscowionych w różnych rejonach świata, jak i na poziomie globalnym, odnoszącym się do całej organizacji międzynarodowej. To powoduje, iż na zarządzanie kadrami w warunkach międzynarodowych należy patrzeć z perspektywy strategicznej (Stor 2010, s. 407-409). Zdaniem Z. Antczaka realizacja funkcji personalnej już na początku XX wieku była coraz częściej rozumiana jako całość, nabierała długookresowego wymiaru, 
w związku z czym zaczęto mówić o strategicznym zarządzaniu zasobami ludzkimi. Częściej także menedżerowie personalni całościowo, systemowo oraz $\mathrm{w}$ dynamicznym ujęciu postrzegali związane z nią procesy (Antczak 2014, s. 20). Zatem pojawia się kolejne pojęcie, które należy uwzględnić w rozważaniach - strategiczne międzynarodowe zarządzanie kadrami (SMZK), które zdaniem T. Listwana „odnosi się do zbioru decyzji i działań związanych z ludźmi, które długofalowo ukierunkowują praktyki w sferze personalnej, są zorientowane na osiąganie celów organizacji międzynarodowej i potrzeb jej pracowników oraz mają zasadnicze i dalekosiężne znaczenie dla powodzenia tej organizacji”" (Stor 2010, s. 407-409). Można zatem wnioskować, iż działania podejmowane w zakresie funkcji personalnej powinny w swoim ogólnym zarysie:

- umożliwiać przedsiębiorstwu zdobywanie globalnej przewagi konkurencyjnej,

- charakteryzować się wysoką efektywnością,

- odpowiadać na potrzeby lokalne,

- mieć doskonałe zdolności adaptacyjne,

- być elastyczne, aby umożliwiać adaptowanie się do nowych warunków w krótkim okresie,

- zapewnić przedsiębiorstwu wysoką zdolność do transferowania wiedzy i umiejętności - w ramach organizacyjnych procesów uczenia się - do poszczególnych, należących do niego jednostek rozporoszonych geograficznie (Stor 2010, s. 407-409).

Jak zauważa A. Pocztowski, aby strategia zarządzania zasobami ludzkimi przyczyniała się znacząco do osiągania przewagi konkurencyjnej przedsiębiorstwa poprzez tworzenie wyjątkowego kapitału ludzkiego i jego efektywne wykorzystanie, musi być ona zintegrowana $\mathrm{z}$ pozostałymi elementami strategicznej konfiguracji przedsiębiorstwa międzynarodowego, a ponadto uwzględniać specyficzne czynniki występujące na rynkach międzynarodowych (Pocztowski 2002, s. 42). Autor wskazuje następujące czynniki mające istotny wpływ na wybory strategiczne w obszarze międzynarodowego zarządzania zasobami ludzkimi:

- filozofia zarządzania zasobami ludzkimi,

- dominująca orientacja strategiczna firmy,

- rodzaj konkurencji,

- stopień umiędzynarodowienia firmy,

- poziom wewnętrznej integracji firmy (Pocztowski 2002, s. 42).

$\mathrm{W}$ odniesieniu do funkcji personalnej w organizacjach międzynarodowych wyróżnia się:

- czynniki egzogenne, związane z zewnętrznym otoczeniem przedsiębiorstwa,

- czynniki endogenne, związane $\mathrm{z}$ wewnętrznym otoczeniem przedsiębiorstwa (Pocztowski 2002, s. 42).

Otoczenie zewnętrzne obejmuje następujące czynniki: prawny, etyczny, polityczny, technologiczny, edukacyjny, socjokulturowy i ekonomiczny. Należy podkreślić, że istota złożoności zarządzania kadrami w organizacjach międzynarodowych nie powinna sprowadzać się jedynie do uwzględniania różnic między otoczeniem zewnętrznym centrali a jednostkami zagranicznymi. Jak zauważa 
M. Stor, niezwykle ważne jest zwrócenie uwagi na pojawiające się we współczesnych społeczeństwach ogólnoświatowe trendy, takie jak:

- globalizacja gospodarki (zagęszczanie i intensyfikowanie powiązań między różnymi sferami życia społeczeństwa),

- dywersyfikacja siły roboczej (odnoszącą się do tzw. różnorodności społecznej),

- rozwój nowych, elastycznych form i warunków zatrudnienia,

- postęp technologiczny, kreujący nowe formy organizacyjne,

- rewolucja jakości,

- oczekiwanie zachowań o wysokiej odpowiedzialności społecznej (Stor 2010, s. 410-411).

Istotne znaczenie w badaniu funkcji personalnej w przedsiębiorstwach międzynarodowych mają tzw. grupy kapitałowe o charakterze międzynarodowym, które poprzez przejęcia i fuzje włączają zagraniczne przedsiębiorstwa w swoje struktury. $\mathrm{Cz}$. Zając stwierdza, iż funkcja personalna $\mathrm{w}$ grupach kapitałowych jest pełniona wyłącznie poprzez zarządzanie zasobami ludzkimi grupy kapitałowej w wymiarze strategicznym oraz $\mathrm{w}$ wymiarze operacyjnym. Zdaniem autora funkcja personalna w grupie kapitałowej jest niezbędna do pełnienia innych funkcji podstawowych, w celu utrzymania pożądanego poziomu wewnątrzorganizacyjnej integracji społecznej, zapewniającej wewnętrzną spoistość zgrupowanych spółek. Ponadto funkcja personalna tworzy społeczne i kulturowe podłoże, konieczne do osiągania celów biznesowych grupy kapitałowej jako całości oraz funkcjonujących w niej podmiotów gospodarczych (Zając 2012, s. 43).

Jak wskazuje K. Gadomska-Lila, zarządzanie zasobami ludzkimi spełnia w organizacji cztery główne funkcje związane z zatrudnianiem personelu, efektywnością pracy, zarządzaniem zmianą oraz skuteczną administracją (GadomskaLila 2013, s. 73). W kwestii zatrudniania personelu niezwykle ważne jest opracowanie przejrzystych procedur dotyczących rekrutacji i selekcji, opracowanie kryteriów dotyczących profilu idealnego kandydata, dogłębnego przemyślenia zakresu czynności i odpowiedzialności kandydata, a potem już pracownika, wskazanie kluczowych kompetencji, wiedzy i doświadczenia, które dany kandydat powinien posiadać. Następnie należy opracować niezwykle istotny plan adaptacyjny (z ang. induction program), który uwzględniał będzie pakiet szkoleń wstępnych, a także pozwoli nowemu pracownikowi szybciej zintegrować się z nową firmą i współpracownikami. $Z$ całą pewnością warto nakreślić możliwy rozwój kariery, aby pracownik miał jasność, w jaki sposób może poszerzać swoje kompetencje, umiejętności, w jakich programach szkoleniowych uczestniczyć, czy też uzyskać awans etc. Pozwoli to $\mathrm{w}$ znacznej mierze uniknąc ewentualnych rozczarowań nowych pracowników wynikających $\mathrm{z}$ braku adekwatnych w odniesieniu do ich wyobrażeń i ambicji możliwości rozwoju kariery zawodowej. Niestety często zdarza się, że pracownik stosunkowo szybko (niespełna po upływie roku albo i szybciej) decyduje się na odejście z nowej firmy, gdyż twierdzi, iż spodziewał się czegoś innego (ciekawszych zadań, udziału w międzynarodowych projektach, licznych szkoleniach wyjazdowych, błyskawicznego awansu etc.). W kwestii efektywności pracy warto zastanowić się, jakie wskaźniki efektywności pracownika wdrożyć (z ang. key performance indicators) i w jaki sposób będą mierzone. Dla pracownika reguły 
te muszą być jasne i precyzyjne, niebudzące najmniejszych wątpliwości, gdyż tylko wówczas pracownik będzie w pełni zaangażowany w realizację zadań, a w konsekwencji - wskaźników. Efektywność pracownika może być badana w oparciu o realizację założonych celów. Stanowi to dobrą podstawę do opracowania atrakcyjnego dla pracownika i skutecznego dla organizacji systemu motywacyjnego, np. premii.

Kolejna funkcja personalna związana z zarządzaniem zmianą jest niezwykle istotna $\mathrm{w}$ sytuacji, gdy organizacja jest $\mathrm{w}$ procesie zmiany, np. przekształcenia właścicielskiego, fuzji, w sytuacji poważnych zmian struktury organizacyjnej (zmiany stanowisk, podległości, redukcja zatrudnienia). Ogromna rola zarządzania zasobami ludzkimi sprowadza się wówczas do efektywnej komunikacji. Z reguły zmiany pracownikom kojarzą się negatywnie i okupione są znacznym stresem, utratą bądź ograniczeniem zaufania do osób zarządzających, dlatego jasna i prowadzona na wszystkich szczeblach komunikacja jest elementem kluczowym. To głównie działy zajmujące się zarządzaniem zasobami ludzkimi odpowiedzialne są za działania związane z budowaniem pozytywnego wizerunku pracodawcy, tzw. employer brandingiem.

Ostatnia z czterech funkcji - skuteczna administracja - związana jest z prowadzeniem nadzoru i kontroli nad przestrzeganiem przepisów i zasad formalnoprawnych $\mathrm{w}$ zakresie nawiązywania, trwania i ustania stosunku pracy, prawidłowym w świetle obowiązującego prawa czasem pracy pracowników oraz naliczaniem wynagrodzeń. J. Purgał $\mathrm{w}$ celu porównania podejścia firm międzynarodowych i krajowych do sprawowania funkcji personalnej, realizowania poszczególnych procesów zarządzania zasobami ludzkimi oraz wykorzystania nowoczesnych rozwiązań informatycznych w tym zakresie, powołuje się na wyniki badań przeprowadzonych w ramach Projektu Celowego Zamawianego Rynek pracy wobec integracji z Uniq Europejska, koordynowanego przez Instytut Pracy i Spraw Socjalnych w Warszawie (Purgał 2002, s. 207-214). Spośród 101 firm, które zwróciły wypełnione ankiety, 29,8\% stanowiły spółki z udziałem kapitału zagranicznego. Warto dodać, iż firmy uwzględnione w analizie, niezależnie od swojej wielkości, miały zróżnicowany terytorialny zasięg działania, a ankietowani wskazali na obecność przedstawicielstw firmy w postaci filii, oddziałów lub biur w różnych krajach świata. J. Purgał przyjęła następujące kryteria w celu oceny podejścia do sprawowania funkcji personalnej:

- znaczenie funkcji personalnej dla osiągnięcia długofalowych celów organizacji;

- zakres uprawnień i pozycja $\mathrm{w}$ organizacji dyrektora lub menedżera ds. zasobów ludzkich;

- rozlokowanie uprawnień i odpowiedzialności za sprawowanie funkcji personalnej.

Wyniki badań ukazały, że w odniesieniu do pierwszego kryterium największe znaczenie ma posiadanie przez firmę strategii zarządzania zasobami ludzkimi, odzwierciedlającej kompleksową, spójną wewnętrznie wizję funkcji personalnej, która uwzględnia strategię ogólną firmy, jej strukturę organizacyjną i kulturę, a także stanowi wspólny mianownik dla wszelkich w tym obszarze procesów, systemów i decyzji. Niestety, mimo że aż 95,5\% ankietowanych wyraziło przekona- 
nie, że strategia zarządzania zasobami ludzkimi jest potrzebna, to nie posiadała jej co czwarta firma $\mathrm{w}$ gronie respondentów. W kwestii drugiego kryterium, czyli zakresu uprawnień i pozycji dyrektora/menedżera ds. zasobów ludzkich, wskazano na znacznie silniejszą pozycję $\mathrm{w}$ przedsiębiorstwach międzynarodowych aniżeli w polskich. Należy dodać, że w ponad $80 \%$ przypadków dyrektor lub kierownik ds. zasobów ludzkich, oczywiście wraz z podległym zespołem, wpływał na kształt następujących procesów personalnych: pozyskiwanie i zwalnianie pracowników, administrowanie sprawami osobowymi, a w 75\% spółek z udziałem kapitału zagranicznego także za obsadzanie stanowisk pracy, szkolenie personelu i kształtowanie wynagrodzeń. W większości tychże przedsiębiorstw był on ponadto współodpowiedzialny za planowanie kariery zawodowej oraz ocenianie efektów pracy załogi, a w co trzeciej firmie odpowiadał także za controlling personalny. Badania pokazały, że uprawnienia decyzyjne w sprawach kadrowych dotyczących bezpośrednich podwładnych przysługiwały kierownikom liniowym równie często jak dyrektorowi ds. zasobów ludzkich lub znacznie częściej. Dość powszechną praktyką było uprawnienie kierownika liniowego do przeprowadzania oceny jego bezpośrednich podwładnych oraz przyznawania im premii lub nagrody. Należy dodać, że ankietowani reprezentujący przedsiębiorstwa międzynarodowe w blisko $75 \%$ przypadków odnotowali udział kierowników liniowych w tworzeniu zasad zarządzania zasobami ludzkimi. Z. Antczak zauważa, że duże, międzynarodowe korporacje z kapitałem zagranicznym częściej realizują funkcję personalną na zaawansowanym poziomie, wykorzystując przy tym szereg narzędzi i stosując między innymi outsourcing, odnoszą znaczne korzyści, redukując przykładowo koszty pracy. Autor wskazuje na charakterystyczną zależność, mianowicie jego zdaniem przedsiębiorstwo uzyskuje wyższy poziom wartości zwrotu z inwestycji w realizację funkcji personalnej, w sytuacji gdy współpracownicy/pracownicy dysponują wysokimi/ rzadkimi kwalifikacjami/kompetencjami i funkcjonują w przestrzeni elastycznych, sieciowo-wirtualnych struktur organizacyjnych oraz relacji (Antczak 2014, s. 31).

\section{Główne problemy i wyzwania zarządzania zasobami ludzkimi w przedsiębiorstwach międzynarodowych}

Jak zauważa A. Sajkiewicz, zmierzanie w kierunku efektywnej organizacji zarządzania personelem nie jest łatwe, wymaga bowiem zarówno trafnego sformułowania celów, jak i wypracowania planu działań i stworzenia warunków jego konsekwentnej realizacji. Autor wymienia kilka zadań, które powinny poprzedzać wdrażanie projektów doskonalenia organizacji systemu personalnego, mianowicie:

- zidentyfikowanie obszarów rynku, na które będą zorientowane procesy i decyzje personalne;

- ustalenie, jakie usługi należy oferować klientom w obszarze personalnym;

- określenie potencjalnych rezerw, które organizacja powinna uruchomić w celu zwiększenia efektywności procesów personalnych;

- wypracowanie narzędzi doskonalenia organizacji działań personalnych oraz analizy porównawczej rozwiązań na tle innych, konkurencyjnych firm; 
- uporządkowanie systemu rachunkowości pod kątem kosztów pracy - poziomu, tworzenia i przepływów, struktury oraz oddziaływania kosztów pracy na inne koszty przedsiębiorstwa (Sajkiewicz 2004, s. 28).

A. Sajkiewicz podkreśla niezwykle istotną dla współczesnego zarządzania zasobami ludzkimi kwestię, iż ,jakościowa zmiana w organizowaniu służby pracowniczej polega na ukształtowaniu jej z myślą o świadczeniu usług klientom, wśród których występują pracownicy, akcjonariusze i klienci zewnętrzni” (Sajkiewicz 2004, s. 28). Tak więc kolejny raz wskazana jest rola wysokich kwalifikacji i świadomości biznesowej pracowników działów HR, jako spore wyzwanie we współczesnych organizacjach, a szczególnie w organizacjach międzynarodowych. Coraz częściej wymaga się, aby komórki/działy personalne stanowiły tzw. wartość dodaną dla firmy. Jednakże aby spełnić to wymaganie, powinny realizować poza zadaniami administracyjnymi zadania dodatkowe, jak na przykład oferować usługi doradcze (w zakresie efektywnego zarządzania personelem), poszukiwać innowacyjnych rozwiązań motywacyjnych, implementować nowe i integrować dotychczasowe procesy, kreować rozwój pracowników i organizacji, wspierać decyzje i funkcje najwyższego kierownictwa. Pogląd, iż zarządzanie zasobami ludzkimi we współczesnych organizacjach winno być ukierunkowane na tworzenie wartości dla interesariuszy wskazuje także A. Pocztowski. Jego zdaniem oznacza to, iż głównym kryterium oceny efektywności działań podejmowanych w zakresie funkcji HR staje się wymierny wkład wnoszony w zaspokajanie potrzeb odbiorców (Pocztowski 2002, s. 294). S. Białas zwraca uwagę na pojawiający się w przedsiębiorstwach międzynarodowych problem dopasowania międzynarodowego, z którym muszą się zmierzyć specjaliści z obszaru zarządzania zasobami ludzkimi. Ponadto według autorki specjaliści muszą nierzadko angażować się w budowanie międzynarodowych zespołów i prowadzenie rekrutacji na obcym rynku pracy, a także mierzyć się z problemami lojalności, tworzenia powiązań i więzi organizacyjnych w wielokulturowych zespołach oraz przezwyciężaniem barier związanych z odmiennością (Białas 2013, s. 45-46). A. Pocztowski z kolei zwraca uwagę na stawianie przed osobami zajmującymi się zarządzaniem zasobami ludzkimi nowych zadań, mających związek z podejmowaniem pracy przez polskich specjalistów w odmiennych kręgach kulturowych, jak i napływ do Polski pracowników z zagranicy, o odmiennej kulturze. Zadania te mają polegać na właściwym przygotowaniu wszystkich pracowników do funkcjonowania w warunkach rosnącej różnorodności kulturowej zatrudnienia, nie tylko tych, którzy wyjeżdżają do pracy za granicę. Zdaniem autora jest to bardzo poważny problem, gdyż opierając się na wielu wynikach badań, można wysnuć, iż występuje dość wysoki odsetek menedżerów i specjalistów doznających niepowodzeń podczas delegowania ich przez macierzyste firmy do pracy na rynkach zagranicznych (Pocztowski 2002, s. 294). Można domniemywać, iż niepowodzenia te mają nie tylko negatywny wpływ na funkcjonowanie działów czy też całej firmy, do której zostali oddelegowani pracownicy, jak i mogą pojawić się kwestie związane z frustracją samych pracowników, skutkujące obniżeniem poziomu satysfakcji z pracy, motywacji do dalszego działania, nadmiernym stresem związanym z nowym otoczeniem, rozłąką z rodziną. Może się zdarzyć, iż nawet wyjątkowo atrakcyjne wynagrodzenie czy pakiet świadczeń dodatkowych 
(pokrycie kosztów relokacji, specjalne premie, pokrycie kosztów podróży do kraju ojczystego etc.) nie będą w stanie zrekompensować w odczuciu pracownika kosztów związanych z pracą poza granicami ojczyzny. Dalszym efektem może być decyzja pracownika o rezygnacji z pracy w zagranicznym oddziale czy też siedzibie firmy, a tym samym konieczność rozpoczęcia przez specjalistów ds. zarzadzania zasobami ludzkimi kosztownego i czasochłonnego procesu rekrutacji. Dlatego też tak ważne jest, aby w porę rozpocząć skuteczne działania, mające na celu minimalizację ryzyka wystąpienia negatywnych aspektów delegowania pracowników.

$\mathrm{W}$ związku z dynamicznie zmieniającą się rzeczywistością biznesową pojawiło się kolejne, ogromne wyzwanie dla działów HR przedsiębiorstw międzynarodowych - mianowicie kwestia edukacji i rozwoju menedżerów. Zdaniem P. Motyla „Nowa rzeczywistość wymusiła zmianę sposobu patrzenia na standardowe procesy zarządzania zasobami ludzkimi. Organizacje nieco inaczej niż w minionej dekadzie traktują kwestię zwrotu z inwestycji w szkolenia i programy rozwojowe, znacznie lepiej rozumiejąc ich rolę. Zaczynają też wyraźniej rozdzielać programy szkoleniowe od programów edukacji menedżerskiej. Kładą większy nacisk na dopasowanie strategii rozwoju personelu do ogólnej strategii firmy. Z większym zaufaniem podchodzą do programów e-learningowych. By nie zostać w tyle, warto nie tylko przyjrzeć się nowym trendom, ale także zrozumieć je i wziąć pod uwagę, planując edukację menedżerów i ich rozwój" (cyt. za Motyl 2016). Jednym z trendów jest zarządzanie talentami i programy sukcesji. Zarządzanie talentami jest wymagającą i najmniej rozumianą kwestią, z jaką borykają się obecnie przedsiębiorstwa międzynarodowe. Należy podkreślić, iż podstawowym elementem efektywnego zarządzania talentami jest planowanie sukcesji dla stanowisk wysokiego szczebla, na które bardzo trudno pozyskać odpowiednich kandydatów z rynku. Sprawia to, że coraz częściej przedsiębiorstwa starają się opracowywać i oferować menedżerom wysokiego szczebla indywidualne programy edukacyjno-rozwojowe, mające zagwarantować silną merytorycznie bazę sukcesorów dla kluczowych w firmie stanowisk. Należy jednak pamiętać, iż każdy program edukacyjno-szkoleniowy, aby odniósł stuprocentową skuteczność, musi być poparty równoległym nabywaniem praktycznych doświadczeń $\mathrm{w}$ strukturach danej organizacji. Dla menedżerów umiejętnie sformułowana i zaprezentowana oferta rozwojowa stanowi skuteczny element składowy pakietu wynagrodzeniowego, szczególnie dla menedżerów o stosunkowo wysokich (lecz nie bardzo wysokich) pensjach. Dla nich bowiem atrakcyjność podwyżki płacy zasadniczej jest stosunkowo mała, jednakże samodzielne sfinansowanie długoterminowego programu edukacyjno-szkoleniowego mogłoby wciąż stanowić problem. Dużą popularnością odznaczają się dobrze przygotowane, nowoczesne programy e-learningowe, a także coaching i mentoring. Natomiast należy zwrócić uwagę, aby wszelkie programy edukacyjno-szkolenioworozwojowe były powiązane ze strategią przedsiębiorstwa, gdyż tylko wtedy będą skuteczne, pozwolą kształtować pozytywny wizerunek organizacji, utrzymać osoby utalentowane oraz zapewnić przewagę konkurencyjną. Na kwestię talentów zwraca uwagę P. Bohdziewicz, stwierdzając, że współczesne zarządzanie kapitałem ludzkim w organizacjach można rozpatrywać w dwóch płaszczyznach: 
- pozyskanie talentów i zatrzymanie ich w organizacji;

- zatrzymanie talentów w organizacji i długofalowe zaangażowanie ich w efektywne realizowanie celów organizacji (Bohdziewicz 2014, s. 110-111).

Z kolei w raporcie What's Next: Future Global Trends Affecting Your Organization, Evolution of Work and the Worker (Co dalej: Przyszle światowe tendencje wptywajace na twoja organizacje, ewolucja pracy i pracownika) wskazuje się na następujące wyzwania dla zarządzania zasobami ludzkimi:

- Dostosowanie się do szybko zmieniającego się profilu pracownika.

- Starzenie się populacji na całym świecie stanowi ogromne wyzwanie dla firm. Młodych pracowników należy szybciej i efektywniej edukować, aby mogli przejąć zadania od starszych pracowników.

- Zrozumienie subtelności kwalifikacji pracowników. Brak standaryzacji w edukacji, zwłaszcza w kontekście globalnym. Stąd też trudno działom HR właściwie ocenić poziom kwalifikacji pracowników, szczególnie spoza granic danego kraju.

- Utrzymanie i angażowanie zmieniającego się rynku pracy. Konieczność uwzględniania przez działy HR preferencji pracowników, gdyż dla jednych największe znaczenie będzie miało wynagrodzenie, dla innych prestiż, a dla jeszcze innych autonomia w pracy. Działy HR będą musiały wszelkie zachęty i systemy motywacyjne dostosować do oczekiwań pracowników, niewystarczające będzie tylko zatrudnienie zdolnych pracowników, ale należy zadbać przede wszystkim o to, aby ich w firmie zatrzymać.

- Wyrównywanie technologii najlepszych praktyk dla globalnej strategii zarządzania. Nowe technologie umożliwiające komunikację poprzez nowe kanały, takie jak e-maile, telefony komórkowe, Internet i wideokonferencje, ułatwiły międzynarodowym przedsiębiorstwom tworzenie transgranicznych zespołów, w których współpracownicy mogą komunikować się ze sobą nieustannie, mimo dzielącej ich czasem znacznej odległości.

- Zarządzanie ryzykiem operacji globalnych. W sytuacji, gdy ludzie spotykają się tylko wirtualnie, a nie twarzą w twarz, pojawiają się trudności w budowaniu atmosfery zaufania i współpracy, częściej powstają także nieporozumienia. Natomiast rzadszy kontakt sprawia, że owe nieporozumienia są trudniejsze do rozwiązania. Dział HR musi się zintegrować z ogólnym zarządzaniem ryzykiem i ciągłością działania oraz planowania w firmie. W szczególności HR będzie musiał być bardziej zaangażowany $\mathrm{w}$ ocenę i przygotowanie do ewentualnych przełomowych wydarzeń, takich jak np. klęski żywiołowe, postoje, przerwy w funkcjonowaniu systemów IT. Ponadto HR będzie musiał szybko zorientować się we wszelkich kwestiach dotyczących kapitału ludzkiego na potencjalnych rynkach.

- Zatrudnianie i zatrzymywanie talentów, przy jednoczesnym obniżeniu kosztów pracy (The Economist Intelligence Unit 2014, s. 32-42).

Zatrzymywanie talentów może okazać się trudne, a pracownicy mogą mieć poczucie, że nie są odpowiednio wynagradzani w odniesieniu do wkładanego wysiłku w realizację zadań. Z kolei pracodawcy mają coraz wyższe oczekiwania względem jakości pracy świadczonej przez pracowników. Pojawiająca się w takiej sytuacji fluktuacja personelu stwarza niewątpliwie wyzwanie dla HR. Zmiany w wieku 
pracowników (starzenie się społeczeństw), więcej pracujących kobiet, profil pracowników (pokolenie Y), elastyczne godziny pracy, niedobór kluczowych/ unikatowych umiejętności, wpływ technologii, oczekiwania pracowników w sprawach wynagradzania za pracę, przenikanie się pracy z życiem prywatnym - powinny zostać skonfrontowane i uwzględnione w strategii HR, gdyż to ludzie są siłą napędową gospodarki opartej na wiedzy. Zatem należy postawić pytanie - czy przedsiębiorstwa są wystarczająco czujne, przygotowane i wyposażone w odpowiednie zasoby, aby sprostać powyższym wyzwaniom? Złożoność i wielość powyższych kwestii stanowi niewątpliwie ogromne wyzwanie dla współczesnych działów zarządzania zasobami ludzkimi.

\section{Studium przypadku}

Przedstawione w niniejszym artykule problemy i wyzwania zarządzania zasobami ludzkimi warto wzbogacić o przykład praktyczny. Literatura przedmiotu podaje wiele przykładów problemów, z którymi borykają się przedsiębiorstwa międzynarodowe. W niniejszym artykule zaprezentowano doświadczenia własne autorki, która na co dzień prowadzi dział HR w międzynarodowym przedsiębiorstwie produkcyjnym średniej wielkości, działającym od kilkunastu lat na rynku polskim. Skupiono się na problematyce absencji chorobowej oraz rezygnacji z pracy, jako obecnie najważniejszych problemach działu HR tej firmy.

W przedsiębiorstwie wyróżniony jest dział zasobów ludzkich, którego kierownik wchodzi w skład kadry zarządzającej. Do kluczowych zadań działu zasobów ludzkich należy zaliczyć:

- administrowanie kadrami,

- rozliczanie czasu pracy pracowników,

- naliczanie wynagrodzeń,

- prowadzenie dokumentacji pracowniczej zgodnie z wymogami prawa,

- rekrutację i selekcję personelu,

- tworzenie i realizacja polityki personalnej,

- badanie potrzeb szkoleniowych,

- organizację szkoleń wewnętrznych i zewnętrznych,

- komunikację wewnętrzną i zewnętrzną,

- kontakt z instytucjami zewnętrznymi: firmy konsultingowo-szkoleniowe, agencje doradztwa personalnego, Państwowa Inspekcja Pracy, Zakład Ubezpieczeń Społecznych,

- opracowywanie i implementacja systemów motywacyjnych,

- przeprowadzanie badania poziomu satysfakcji pracowników,

- wsparcie kadry kierowniczej w zakresie prawa pracy i zarządzania personelem,

- sprawozdawczość i raportowanie - realizacja i monitoring założonych wskaźników efektywności,

- bieżącą obsługę pracowników w zakresie spraw kadrowo-płacowych. 


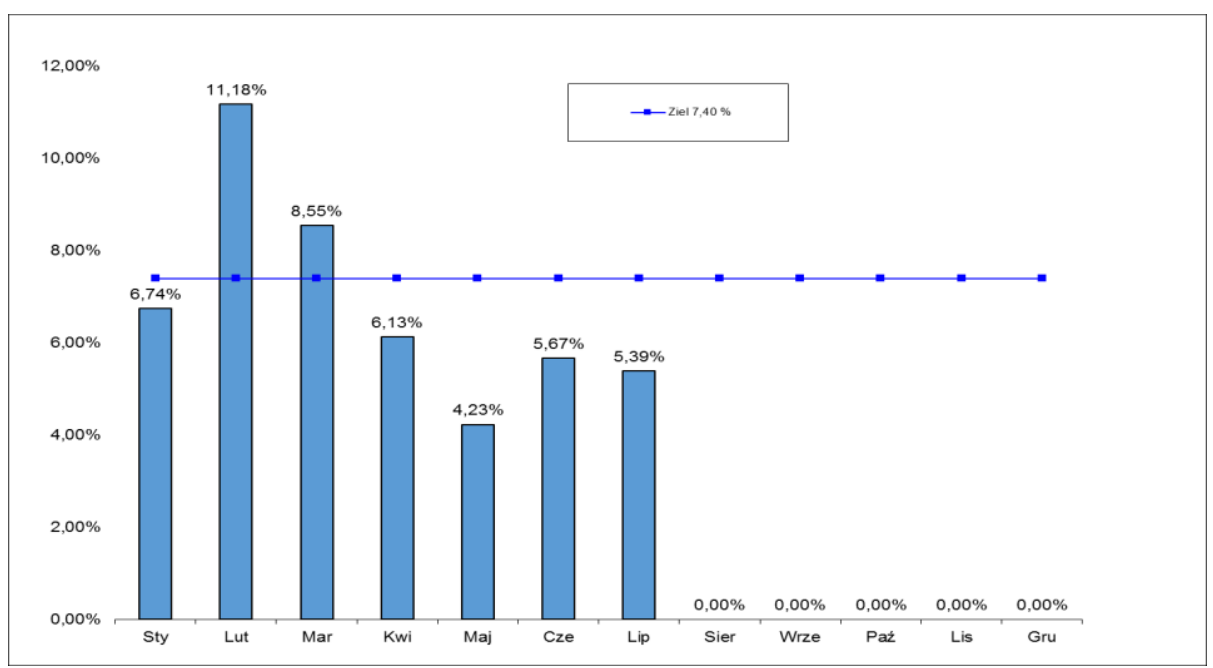

Rysunek 1. Absencja chorobowa wszystkich pracowników w roku 2015

Źródło: Opracowanie własne na podstawie danych z przedsiębiorstwa $\mathrm{X}$

Kluczowe problemy, z którymi można było się spotkać w ostatnim roku w badanej firmie, dotyczą dużej absencji oraz rotacji pracowników. Ukazane problemy mają ogromny wpływ na globalne funkcjonowanie organizacji. W tym celu w opracowaniu przedstawiono wskaźnik absencji oraz rotacji pracowników i wskazano na zmiany, które powinny zostać wprowadzone w zarządzaniu działem zasobów ludzkich. W badanej firmie wskaźnik absencji (absencji chorobowej) obliczany jest w następujący sposób: stosunek liczby dni tzw. L-4 do liczby dni kalendarzowych w miesiącu. Sposób wyliczeń był wymogiem zarządu firmy. Do pewnego momentu w skład współczynnika absencji wliczano także zwolnienia pracowników przebywających na zasiłkach chorobowych czy też świadczeniach rehabilitacyjnych, które de facto nie stanowią bezpośredniego kosztu pracodawcy, aczkolwiek życzeniem zarządu było uwzględnianie tych danych w prowadzonych statystykach. Wydawać się może, że otrzymane w ten sposób wyniki nie są do końca rzeczywiste i są mocno zawyżone. Jednakże uwzględniając kwestię, iż za nieobecnych pracowników ktoś musiał jednak wykonywać pracę, chociażby w godzinach nadliczbowych, generując tym samym zarówno dodatkowe koszty, jak i powodując nieprawidłowości w czasie pracy, można zrozumieć taki sposób postrzegania tego współczynnika. $Z$ analiz wynikało, iż najwyższy współczynnik absencji wygenerował dział produkcji, a najniższy pracownicy biurowi. Wynika to z faktu, iż pracownicy działu produkcji stanowią ponad $60 \%$ wszystkich zatrudnionych pracowników. Warto zwrócić uwagę, że najwyższa wartość wskaźnika miała miejsce w miesiącach zimowych oraz letnich - wakacyjnych (Rysunek 1). W miesiącach zimowych obserwowano zwiększoną zachorowalność na schorzenia przeziębieniowo-grypowe, natomiast $\mathrm{w}$ okresie letnim absencja spowodowana była między innymi schorzeniami/urazami układu kostno-szkieletowego. Funkcjonujący 
w organizacji dział zasobów ludzkich wprowadził rozmowy z pracownikami powracającymi do pracy po absencji chorobowej, mające na celu pozyskanie informacji, czy absencja miała związek $\mathrm{z}$ wykonywaną pracą. $\mathrm{W}$ wyniku przeprowadzonych rozmów wskazano na brak związku pomiędzy absencją chorobową a wykonywaną pracą. Pierwotnym założeniem było, aby rozmowy z pracownikami były prowadzone przez bezpośrednich przełożonych. Niestety nie przyniosło to oczekiwanego skutku - przełożeni tłumaczyli się notorycznym brakiem czasu i z reguły rozmowy wcale nie były przeprowadzane. $Z$ tego względu rola rozmówcy z pracownikami przypadła działowi zasobów ludzkich. Pozwoliło to nawiązać bezpośredni kontakt z pracownikami, a także monitorować przewlekłe schorzenia i wyselekcjonować pracowników potrzebujących pomocy finansowej (w ramach środków z Zakładowego Funduszu Świadczeń Socjalnych) ze strony przedsiębiorstwa ze względu na poważne problemy zdrowotne.

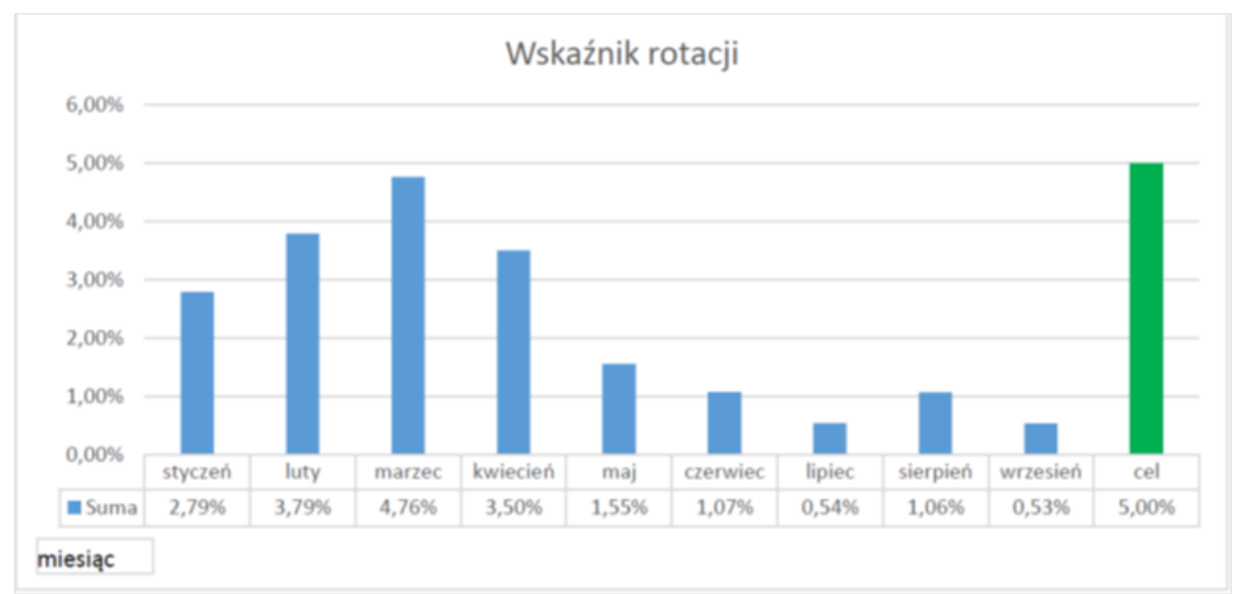

Rysunek 2. Wskaźnik rotacji pracowników w roku 2015

Źródło: Opracowanie własne na podstawie danych z przedsiębiorstwa $\mathrm{X}$

Kolejny problem badanego przedsiębiorstwa stanowi rotacja personelu, wynikająca w $90 \%$ z inicjatywy pracownika, przedstawiona na Rysunku 2 . W tym przypadku wskaźnik rotacji był znacznie wyższy pośród pracowników umysłowych (biurowych) niż pracowników bezpośrednio i pośrednio produkcyjnych (pracownicy działu jakości, utrzymania ruchu). Mimo iż powyższy wskaźnik zazwyczaj mieści się w celu, to z uwagi na fakt stosunkowo małej liczby pracowników umysłowych stanowi duży problem. Dział zasobów ludzkich przeprowadzał rozmowy z każdym pracownikiem składającym wypowiedzenie, pytając o przyczynę podjętej decyzji. Najczęstsze powody odejścia z firmy podawane przez pracowników produkcyjnych to:

- niesatysfakcjonujące wynagrodzenie - stawka godzinowa;

- wyjazd do pracy za granicę;

- wysokie koszty dojazdu do pracy związane z odległością od miejsca zamieszkania. 
- Najczęstsze powody odejścia z firmy przez pracowników biurowych to:

- otrzymanie atrakcyjniejszej oferty pracy pod względem finansowym;

- brak oczekiwanych możliwości rozwoju - wyższego w hierarchii stanowiska;

- brak systemu motywacyjnego;

- atmosfera i warunki pracy - informacja pozyskana nieformalnie (w trakcie tzw. rozmów kuluarowych).

Uwagę zwraca fakt, iż większosśc odejść pracowników umysłowych ma miejsce przed upływem jednego roku od zatrudnienia.

Bezpośrednim problemem samego działu zasobów ludzkich jest konieczność zbyt dużej koncentracji na kwestiach administracyjnych i polityce kosztowej, polegająca na wykonywaniu ogromnej ilości zestawień, raportów, analiz. Takie są bowiem oczekiwania i wytyczne zarządu przedsiębiorstwa. Niestety całkowicie na dalszy plan zeszły tak istotne w obecnych czasach kwestie, jak komunikacja na linii przełożony-pracownik, szkolenia i rozwój pracowników czy systemy motywacyjne. Jest to dość powszechne zjawisko w firmach właścicielskich, sterowanych ręcznie, w których mamy do czynienia $\mathrm{z}$ afektem ojcowskim, tzn. tylko to, co stworzy/zaproponuje zarząd/właściciel jest słuszne i przekazywane do realizacji. Taka sytuacja z całą pewnością oddziałuje na wyżej wymienioną rotację pracowników umysłowych - specjalistów, oczekujących samodzielności, większej swobody działania, decyzyjności, możliwości implementowania własnych pomysłów. Oczywiście ma to negatywny wpływ na ogólny wizerunek przedsiębiorstwa na rynku pracy i trudności z pozyskaniem nowych, kompetentnych kandydatów.

\section{Podsumowanie}

Podsumowując powyższe rozważania, z całą pewnością należy podkreślić fakt, iż firmy międzynarodowe odgrywają ogromną rolę w tworzeniu nowoczesnych strategii i metod zarządzania zasobami ludzkimi. Współczesne działy zajmujące się zarządzaniem zasobami ludzkimi muszą dbać o swój profesjonalny wizerunek poprzez ciągłe doskonalenie swoich kompetencji, aktualizowanie wiedzy, a także bieżący monitoring aktualnych trendów i najlepszych praktyk w dziedzinie zarządzania zasobami ludzkimi, korzystanie z nowoczesnych rozwiązań systemowych (np. oprogramowania IT). Liczne badania potwierdzają trend w przekształcaniu się ról menedżerów i specjalistów ds. zarządzania zasobami ludzkimi oraz coraz wyższy poziom ich profesjonalizmu. Jednakże kwestia zmiany ról działów zarządzania zasobami ludzkimi wciąż postrzegana jest jako wyzwanie na przyszłość aniżeli jako aktualny standard. Ważne, aby osoby zajmujące się dziedziną HR uczyły się wychodzenia z dotychczasowych ról „kadrowych” i brały czynny udział we wszelkich zmianach organizacyjnych, koncentrowały się na celach strategicznych przedsiębiorstwa, wykazywały się inicjatywą, kreatywnością, pozbawionym stereotypów myśleniem. Ponadto powinny systematycznie dostarczać klientom wewnętrznym (menedżerom, zarządom, pracownikom) mierników, będących nie tylko dowodem na efektywne, skuteczne działanie, ale będących konkretnymi informacjami wspierającymi procesy decyzyjne związane $\mathrm{z}$ globalnym funkcjonowaniem przedsiębior- 
stwa. Niewątpliwym problemem są przedsiębiorstwa, w których działy HR nie są doceniane, a ich rola mimo posiadanych kompetencji i chęci uczestnictwa w decyzjach strategicznych jest bagatelizowana i sprowadzana wyłącznie do funkcji administracyjnej.

\section{Literatura}

1. Antczak Z. (2014), Kierunki rozwoju funkcji personalnej w organizacjach w Polsce, [w:] Z. Antczak, S. Borkowska (red.), Przyszłość zarządzania zasobami ludzkimi. Dylematy i wyzwania, Difin, Warszawa.

2. Armstrong M. (2010), Strategiczne zarządzanie zasobami ludzkimi, Wolters Kluwer, Warszawa.

3. Bazan-Bulanda A., Robak E. (red.) (2014), Wybrane problemy zarządzania zasobami ludzkimi we współczesnych organizacjach, Sekcja Wydawnictw Wydziału Zarządzania Politechniki Częstochowskiej, Częstochowa.

4. Białas S. (2013), Zarządzanie zasobami ludzkimi w otoczeniu międzynarodowym, Wydawnictwa Profesjonalne PWN, Warszawa.

5. Bohdziewicz P. (2014), Współczesne przeobrażenia psychologicznego kontraktu zatrudnienia i ich konsekwencje jako wyzwanie dla zarządzania zasobami ludzkimi, [w:] Antczak Z., Borkowska S. (red.), Przyszłość zarządzania zasobami ludzkimi. Dylematy i wyzwania, s. 92-109, Difin, Warszawa.

6. Borkowska S. (red.) (2007), Zarządzanie zasobami ludzkimi w Polsce. Przeszłość, teraźniejszość, przyszłość, Wolters Kluwer, Kraków.

7. Bylok F., Słocińska A. (2011), Kapitał ludzki i intelektualny jako elementy kształtujące przewagę konkurencyjną organizacji. Wprowadzenie do tematyki, [w:] Bylok F., Słocińska A. (red.), Współczesne oblicza kapitału ludzkiego i intelektualnego, Wydawnictwo Politechniki Częstochowskiej, Częstochowa.

8. Gadomska-Lila K. (2013), Dopasowanie organizacyjne. Aspekt strategii, kultury organizacyjnej i zarządzania zasobami ludzkimi, Difin, Warszawa.

9. Griffin R.W. (2013), Podstawy zarządzania organizacjami, Wydawnictwo Naukowe PWN, Warszawa.

10. Juchnowicz M. (red.) (2004), Standardy europejskie w zarządzaniu zasobami ludzkimi, Poltext, Warszawa.

11. Listwan T. (red.) (2010), Zarządzanie kadrami, C.H. Beck, Warszawa.

12. Motyl P. (2016), Edukacja i rozwój menedżerów: nowe trendy, największe wyzwania, http://www.ican.pl/172,1,edukacja_i_rozwoj_menedzerow_nowe_trendy_najwieksze_wyzw ania (dostęp: 20.06.2016).

13. Pocztowski A. (red.) (2002), Międzynarodowe zarządzanie zasobami ludzkimi, Oficyna Ekonomiczna, Kraków.

14. Pocztowski A. (2007), Wokół strategicznych problemów i kierunków rozwoju ZZL, [w: ] S. Borkowska, Zarządzanie zasobami ludzkimi w Polsce. Przeszłość, teraźniejszość, przyszłość, Oficyna a Wolters Kluwer business, Kraków.

15. Purgał J. (2002), Zarządzanie zasobami ludzkimi w przedsiębiorstwach międzynarodowych działających w Polsce, [w:] A. Pocztowski (red.), Międzynarodowe zarządzanie zasobami ludzkimi, Oficyna Ekonomiczna, Kraków.

16. Sajkiewicz A. (2004), Standardy organizacji zasobów ludzkich, [w:] M. Juchnowicz (red.), Standardy europejskie w zarządzaniu zasobami ludzkimi, Poltext, Warszawa.

17. Stor M. (2010), Międzynarodowe zarządzanie kadrami, [w:] T. Listwan (red.), Zarządzanie kadrami, C.H. Beck, Warszawa. 
18. Ulrich D., Brockbank W. (2013), Tworzenie wartości przez dział HR, Wolters Kluwer, Warszawa.

19. The Economist Intelligence Unit (2014), What's Next: Future Global Trends Affecting Your Organization, Evolution of Work and the Worker, New York,

20. http://futurehrtrends.eiu.com/report-2014/challenges-human-resource-management/ (dostęp: 20.06.2016).

21. Zając Cz. (2012), Zarządzanie zasobami ludzkimi w grupach kapitałowych, PWE, Warszawa.

\title{
CONTEMPORARY ISSUES AND CHALLENGES OF HUMAN RESOURCES MANAGEMENT IN INTERNATIONAL ORGANIZATIONS
}

\begin{abstract}
This article takes issues related to human resources management in international companies. It is trying to identify the role of human resources departments at the present time, which must often demonstrate both great initiative and flexibility in their daily activities, to play the role of not only the data personal and payroll, but the major role of strategic business partner. Theoretical considerations supplemented with case studies presenting the main problems in the HR department in an international company.
\end{abstract}

Keywords: human resources, human resources management, international companies 